\title{
Severity of Lethal Ischemia/Reperfusion Injury in Rat Hearts Subjected to Ischemic Preconditioning Is Increased Under Conditions of Simulated Hyperglycemia
}

\author{
M. ZÁLEŠÁK ${ }^{1}$, P. BLAŽÍČEK ${ }^{2}$, D. PANCZA ${ }^{1}$, V. LEDVÉNYIOVÁ ${ }^{1}$, M. BARTEKOVÁ ${ }^{1}$, \\ M. NEMČEKOVÁ ${ }^{1}$, S. ČARNICKÁ ${ }^{1}$, A. ZIEGELHÖFFER ${ }^{1}$, T. RAVINGEROVÁ ${ }^{1}$ \\ ${ }^{1}$ Institute for Heart Research, Slovak Academy of Sciences and Centre of Excellence of SAS \\ NOREG Bratislava, Slovak Republic, ${ }^{2}$ Laboratory of Clinical Biochemistry and Hematology Alpha \\ Medical, Bratislava, Slovak Republic
}

Received September 2, 2013

Accepted March 7, 2014

On-line June 5, 2014

\begin{abstract}
Summary
The aim of our study was to characterize resistance to ischemia/reperfusion (I/R) injury in Langendorff-perfused rat hearts and effectivity of ischemic preconditioning (PC) under condition of simulated acute hyperglycemia (SAHG) by perfusion of the hearts with Krebs-Henseleit $(\mathrm{KH})$ solution with elevated glucose concentration ( $22 \mathrm{mmol} / \mathrm{l})$. I/R injury was induced by 30 min coronary occlusion followed by 120 -min reperfusion and PC by two cycles of 5-min occlusion/5-min reperfusion, prior to I/R. The severity of $I / R$ injury was characterized by determination of the size of infarction (IS, expressed in \% of area at risk size) and the amount of heart-type fatty acid binding protein (h-FABP, a marker of cell injury) released from the hearts to the effluent. Significantly smaller IS $(8.8 \pm 1 \%)$ and lower total amount of released h-FABP $(1808 \pm 660 \mathrm{pmol})$ in PC group compared with IS $17.1 \pm 1.2 \%(p<0.01)$ and amount of h-FABP $(8803 \pm 2415$ pmol, $\mathrm{p}<0.05)$ in the non-PC control hearts perfused with standard $\mathrm{KH}$ solution (glucose $11 \mathrm{mmol} / \mathrm{l}$ ) confirmed protective effects of PC. In contrast, in SAHG groups, PC enhanced IS (21.4 \pm 2.2 vs. $14.3 \pm 1.3 \%, p<0.05)$ and increased total amount of h-FABP $(5541 \pm 229$ vs. $3458 \pm 283$ pmol, $\mathrm{p}<0.05)$ compared with respective non-PC controls. Results suggest that $\mathrm{PC}$ has negative effect on resistance of the hearts to $I / R$ injury under conditions of elevated glucose in vitro.
\end{abstract}

\section{Key words}

Acute myocardial infarction - h-FABP - Ischemia/reperfusion injury • Ischemic preconditioning • Simulated hyperglycemia

\section{Corresponding author}

M. Zálešák, Institute for Heart Research, Slovak Academy of Science, P.O. BOX 104, Dúbravská cesta 9, 84005 Bratislava, Slovak Republic. E-mail: mzmzalesak@gmail.com

\section{Introduction}

Many clinical studies describe protective effects of unstable angina pectoris (UAP) considered as clinical analogue of ischemic preconditioning (PC) (Kloner 1995, Kloner et al. 1998, Nakagawa et al. 1995, Švorc et al. 2003). In contrast, other authors observed higher mortality in UAP patients than in non-UAP patients after acute myocardial infarction (AMI) (Behar et al. 1992). Distinct effects of UAP can be attributed to different personal history (e.g., presence of comorbidities, such as diabetes mellitus, hypertension). Clinical and epidemiological studies demonstrated a higher risk of cardiovascular disorders in diabetic patients and a loss of protective effect of UAP (Ishihara et al. 2001). On the other hand, experimental data are not unequivocal and suggest that besides higher myocardial vulnerability, diabetes mellitus may be associated with induction of adaptive processes leading to lower susceptibility to ischemia similar to PC (Ravingerová et al. 2011, Balakumar and Sharma 2012). The first paradoxical effects of diabetes have been observed in diabetic rats subjected to ischemia/reperfusion (I/R) injury reflected in better recovery of contractile function and reduced $\mathrm{Ca}^{2+}$ 
overload upon I/R (Tani and Neely 1988). The probable cause of attenuated $\mathrm{Ca}^{2+}$ overload in the diabetic myocardium is decreased accumulation of glycolytic products and inhibition of $\mathrm{Na}^{+} / \mathrm{H}^{+}$exchanger activity (Feuvray and Lopaschuk 1997, Karmazyn 1995). Likewise, Liu et al. (1993) observed antiinfarct effect in the acute phase of streptozotocin (STZ)-induced diabetes mellitus. Duration of diabetic state significantly influences myocardial response to ischemia. Experimental studies have shown that increased resistance to $\mathrm{I} / \mathrm{R}$ injury in the acute phase of disease can be reversed in the chronic phase of diabetes (Balakumar and Sharma 2012). Experiments with isolated Langendorff-perfused rat hearts demonstrated decreased antiarrhytmic effect (Ravingerová et al. 2000) and reduction of improved postischemic contractile recovery associated with prevention of ion shifts (Tosaki et al. 1996) in the chronic (8-9 weeks) phase in comparison with acute ( 1 or 2 week) phase of STZ-induced diabetes. In addition, loss of antiinfarct protection (reduction of infarct size) in the diabetic rats was observed in the chronic phase of the disease in the open-chest in vivo animals (Ravingerová et al. 2003).

Experimental studies showed that diabetes can also modulate effectivity of PC. In normal physiological conditions, insulin can regulate glucose metabolism through phosphoinositide 3-kinase (PI3K)/ protein kinase B (Akt) pathway (component of PC cascade) and phosphorylation (and inactivation) of glycogen synthase kinase $3 \beta$ (GSK3ß). The latter is known to promote glucose utilization and mitochondrial permeability transition (mPTP) pores closing (Yin et al. 2012). Active GSK3ß plays a role in necrosis and apoptosis of cardiomyocytes due to $\mathrm{MPTP}$ pores opening triggered by tumor suppressor protein 53 (p53) phosphorylation (Miura et al. 2009) and regulation of glycogen synthesis (Montori-Grau 2013). In accordance, the antiinfarct effect of PC in hearts isolated from rats with STZ-induced diabetes was evident only in the case of treatment with GSK3ß inhibitor (Yadav et al. 2010). However, hyperglycemia can abrogate PC effect independently of insulin level, too (Clodfelder-Miller et al. 2005), e.g., by increasing the threshold for antiinfarct protection that requires a higher number of $\mathrm{PC}$ cycles (Tsang et al. 2005).

Clinical studies demonstrated that heart-type fatty acid binding protein (h-FABP) has a high potential as an early marker of AMI. It is a low-molecular weight cytoplasmic protein (about 14-15 kDa with 126-134 amino acids in molecule) found in abundance in the heart and released from cardiomyocytes early after the onset ischemia (Chan et al. 2004, Veerkamp et al. 1999). h-FABP test could be considered as highly specific in the diagnosis of AMI (Alhadi and Fox 2004) with more than $80 \%$ sensitivity of this cardiomarker maintained within first three hours after an ischemic attack (Kleine et al. 1992). However, clinical studies revealed increased levels of h-FABP in the serum of UAP patients than were lower than in AMI patients (Tsuji et al. 1993). Therefore, hFABP migh be also regarded as an indicator of reversible damage of myocardial integrity occurring without necrosis.

Aims of our study were to find differences in the size of myocardial infarction and in the release of h-FABP between the hearts of control nonpreconditioned and ischemically preconditioned groups, both under standard conditions and under conditions of simulated hyperglycemia. Our second goal was to reveal mutual correlation between the total amount of released h-FABP and the extent of lethal injury (infarct size).

\section{Material and Methods}

\section{Animals and experimental protocols}

Adult male Wistar rats (250-300 g body weight) fed a standard diet and tap water ad libidum were used in the experiments. Animals were anesthetized by sodium pentobarbitone in dose $50-60 \mathrm{mg} / \mathrm{kg}$ combined with heparin. All studies were performed in accordance with the Guide for the Care and Use of Laboratory Animals published by US National Institutes of Health (NIH publication No 85-23, revised 1996) and approved by the Animal Health and Animal Welfare Division of the State Veterinary and Food Administration of the Slovak Republic. Rats were randomly divided into four groups, and further experiments were performed in Langendorffperfused hearts.

\section{Perfusion technique}

After rapid excision, the hearts were placed in ice-cold perfusion buffer, cannulated via the aorta and then perfused in the Langendorff mode with KrebsHenseleit $(\mathrm{KH})$ solution gassed with $95 \% \mathrm{O}_{2}$ and $5 \%$ $\mathrm{CO}_{2}$ (pH 7.4) at constant perfusion pressure of $73 \mathrm{~mm} \mathrm{Hg}$ and $37^{\circ} \mathrm{C}$. $\mathrm{KH}$ solution contained (in mmol/l): $\mathrm{NaCl}$ 118.0; $\mathrm{KCl} 3.2 ; \mathrm{MgSO}_{4} 1.2 ; \mathrm{NaHCO}_{3} 25.0 ; \mathrm{KH}_{2} \mathrm{PO}_{4}$ 1.18; $\mathrm{CaCl}_{2}$ 2.5; glucose 11.1 or 22.2. Left ventricular (LV) pressure was measured by a water-filled balloon 
(inflated to obtain end-diastolic pressure of 5-7 $\mathrm{mm} \mathrm{Hg}$ ) inserted into LV and connected to a pressure transducer (MLP physiological pressure transducer, ADInstruments, Germany). LV systolic and diastolic pressure, LV developed pressure (LVDP; systolic minus diastolic pressure), maximal rates of pressure development and fall, $+\mathrm{dP} / \mathrm{dt}_{\max }$ and $-\mathrm{dP} / \mathrm{dt}_{\max }$, as indexes of contraction and relaxation, heart rate (HR, derived from electrogram) and coronary flow were used to assess heart function using Power-Lab/8SP Chart 7 software (ADInstruments, Germany). The hearts were allowed to stabilize (15 min) before further interventions.

\section{Protocols of ischemia/reperfusion}

1. In the control normoglycemic (C/NG) and hyperglycemic $(\mathrm{C} / \mathrm{HG})$ groups, the hearts were exposed to 30-min occlusion of left anterior descending (LAD) coronary artery followed by a release of clamping and 120-min reperfusion. During the whole protocol, the hearts were perfused either with standard KH solution (concentration of glucose $11 \mathrm{mmol} / \mathrm{l}$ ) or with $\mathrm{KH}$ solution containing $22 \mathrm{mmol} / 1$ glucose. Numbers of animals per group were $8(\mathrm{C} / \mathrm{NG})$ and $6(\mathrm{C} / \mathrm{HG})$.

2. In the preconditioned normoglycemic (PC/NG) and hyperglycemic $(\mathrm{PC} / \mathrm{HG})$ groups, the hearts were subjected to two cycles of ischemic preconditioning (PC) induced by 5-min LAD occlusion followed by 5 min reperfusion, prior to sustained $\mathrm{I} / \mathrm{R}$ as in 1 . Numbers of animals per group were $9(\mathrm{PC} / \mathrm{NG})$ and 4 (PC/HG).

\section{Determination of infarct size}

Infarct size (IS) and area at risk (AR) size were delineated by double-staining with $\mathrm{KMnO}_{4}$ and 2,3,5triphenyltetrasolium chloride (TTC), as described elsewhere (Ravingerová et al. 2003). IS and AR were measured in 4-5 slices per heart (1 mm thick) and determined by noncommercial planimetric software. IS was expressed in \% of AR. In one experiment in PC/NG group, the staining failed to provide the required information.

\section{Analysis of h-FABP released from the hearts}

Heart effluent was collected during stabilization, long-term occlusion and reperfusion period. Collecting during reperfusion was divided into six $20 \mathrm{~min}$ separated portions. Samples $(2 \mathrm{ml})$ from effluent portions were dialyzed overnight against redistilled water at $4{ }^{\circ} \mathrm{C}$ using dialysis tubing cellulose membrane, 1-ml samples obtained from dialyzed samples were frozen at $-20{ }^{\circ} \mathrm{C}$, completely lyophilized and subsequently diluted with $110 \mu \mathrm{l}$ of sample diluent. Diluted samples $(100 \mu \mathrm{l})$ were analyzed by rat h-FABP ELISA test kit (sandwich ELISA) according to the manual from the manufacturer to determine h-FABP concentration. Concentration values were multiplied by values of collected volumes to determine the amount of h-FABP substance (in pmol) in every portion. With respect to the sample processing, values of h-FABP amounts were multiplied by 0.09 . This constant represents a simplified numeric expression of $100 / 1000 \times 100 / 110$. Summation of amounts from all previous portions and the amount of actual collected portion was considered as a real value in a respective stage of experiment. Requirement for concentration analysis of hFABP was the value of coronary flow within the calibrated range during the whole experiment. For these reasons, the data from two experiments in $\mathrm{PC} / \mathrm{NG}$ and in $\mathrm{C} / \mathrm{HG}$ groups (one per group), as well as from two experiments in $\mathrm{C} / \mathrm{NG}$ group were excluded from the analysis. The criterion for subsequent calculation of hFABP amounts was the concentration value no lower than the lowest standard concentration $(16 \mathrm{pmol} / \mathrm{ml})$. In three experiments in $\mathrm{C} / \mathrm{NG}$ group, where detected concentration values were below this level in all samples, the results of the test were considered as insensitive or false negative. Data related to h-FABP in these experiments were not included in statistical analysis.

\section{Statistical evaluation}

All data are expressed as means \pm SEM. Comparison of individual groups was performed by Student's $t$-test. Criterion for significant difference between the groups was value $p<0.05$. To verify the possible statistical correlation of total amount of h-FABP in the effluent from the hearts with the infarct size, the calculation of the Pearson's correlation coefficient (r) was used. Computed modified Z-scores (Iglewicz and Hoaglin 1993) were used for testing for outliers. Due to exclusion of extreme values of released total h-FABP in PC/NG and in $\mathrm{PC} / \mathrm{HG}$ groups (one experiment per group) data associated with released h-FABP in these experiments were not included in statistical analysis.

\section{Results}

Characteristic of isolated hearts

The value of heart rate, $\mathrm{LVDP},+\mathrm{dP} / \mathrm{dt}_{\max }$, 
$-\mathrm{dP} / \mathrm{dt}_{\max }$, and coronary flow in the $\mathrm{NG}$ and $\mathrm{HG}$ control groups, as well as in the preconditioned $\mathrm{NG}$ and $\mathrm{HG}$ groups are summarized in Table 1. There were no significant differences in the values of these parameters between the groups prior to ischemia.

Table 1. Preischemic values of parameters of myocardial function in controls and ischemically preconditioned rat hearts.

\begin{tabular}{lcccc}
\hline Group & C/NG & PC/NG & C/HG & PC/HG \\
\hline$H R($ beats/min) & $263 \pm 21$ & $228 \pm 23$ & $269 \pm 12$ & $221 \pm 30$ \\
$C F(\mathrm{ml} / \mathrm{min})$ & $8.2 \pm 0.7$ & $8.0 \pm 1.1$ & $12.6 \pm 1.7$ & $10.8 \pm 1.0$ \\
$L V D P(\mathrm{~mm} \mathrm{Hg})$ & $81.6 \pm 4.7$ & $79.8 \pm 7.8$ & $87.5 \pm 5.8$ & $69.3 \pm 9.5$ \\
$+(d P / d t)_{\max }(\mathrm{mm} \mathrm{Hg} / \mathrm{s})$ & $2125 \pm 242$ & $2061 \pm 353$ & $2309 \pm 258$ & $2077 \pm 198$ \\
$-(d P / d t)_{\max }(\mathrm{mm} \mathrm{Hg} / \mathrm{s})$ & $1158 \pm 138$ & $1178 \pm 193$ & $1490 \pm 95$ & $1156 \pm 100$ \\
\hline
\end{tabular}

C - controls, PC - ischemic preconditioning. HR - heart rate, CF - coronary flow, LVDP - left ventricular developed pressure, $+(\mathrm{dp} / \mathrm{dt})_{\max }-$ maximal rate of pressure development, $-(\mathrm{dP} / \mathrm{dt})_{\max }-$ maximal rate of pressure fall. Data are expressed as means $\pm \mathrm{SEM}$, $n=4-9$ hearts per group.

A.

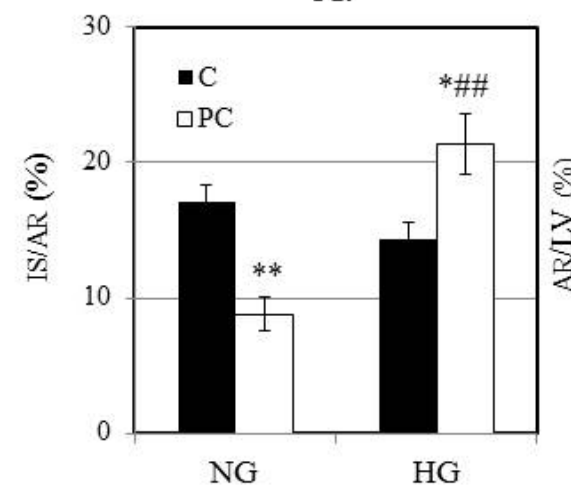

B.

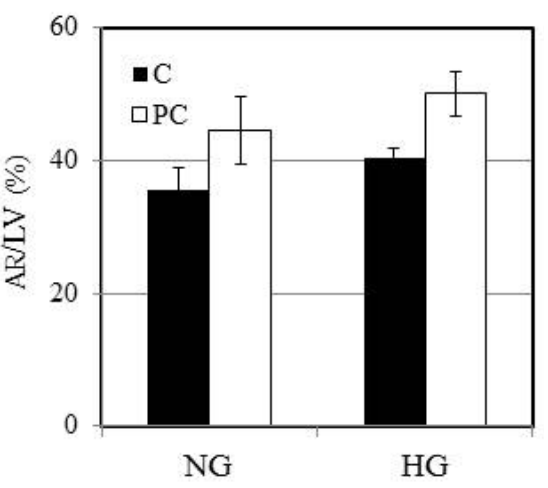

Fig. 1. The effect of hyperglycemia on size of myocardial infarction and area at risk size in the preconditioned rat hearts and in non-preconditioned control hearts. A: Infarct size/area at risk (IS/AR) ratio. B: Area at risk/left ventricle size (AR/LV) ratio. IS infarct size, AR - area at risk, LV - left ventricle, NG - groups perfused with standard KH solution, HG - groups exposed to simulated hyperglycemia, C - non-PC control groups, PC preconditioned groups. Results are means $\pm S E M, n=4-8$ hearts per group. * $\mathrm{p}<0.05, * * \mathrm{p}<0.01, \mathrm{PC}$ vs. $\mathrm{C}$, $\# \#$ p $<0.01, P C / H G$ vs. PC/NG
Infarct size in non-preconditioned controls and preconditioned groups under $N G$ and $H G$ conditions

Under NG conditions, significantly smaller infarct size was observed in the PC group than in the control non-PC group $(8.8 \pm 1.0 \%$ vs. $17.1 \pm 1.2 \%$, $\mathrm{p}<0.01)$. Under HG conditions, in the PC group, infarct size was significantly larger than in the control non-PC group $(21.4 \pm 2.2 \%$ vs. $14.3 \pm 1.3 \%, \quad \mathrm{p}<0.05)$. No significant difference in IS/AR ratio between the control non-preconditioned groups was observed. On the contrary, in the preconditioned hearts, significantly higher IS/AR ratio was found in the $\mathrm{HG}$ group as compared with preconditioned $\mathrm{NG}$ group $(\mathrm{p}<0.01)$ (Fig. 1A). No significant differences in the size of area at risk (AR/LV ratio) among all the groups were observed (Fig. 1B).

Cumulative curves of amount of H-FABP substance released from the hearts in the non-preconditioned controls and preconditioned hearts under $N G$ and $H G$ conditions

Under NG conditions, amount of h-FABP substance released from the hearts was significantly lower in the 100th and the 120th min of long-term reperfusion in the PC group than in the non-PC control group $(1677 \pm 626$ and $1808 \pm 660$ vs. $6189 \pm 1765$ and $8803 \pm 2415$ pmol, $\mathrm{p}<0.05$, respectively) (Fig. 2A). In contrast, in $\mathrm{HG}$ conditions, during long-term reperfusion, h-FABP was higher in the PC group than in the control non-PC group starting from the 60th min of reperfusion $(3183 \pm 415, \quad 3936 \pm 396, \quad 4521 \pm 442, \quad 5541 \pm 229 \quad$ vs. $1345 \pm 558, \quad 1812 \pm 532, \quad 2651 \pm 415, \quad 3458 \pm 283$ pmol, respectively, $\mathrm{p}<0.05$ ) (Fig. $2 \mathrm{~B}$ ). In both conditions, the most significant difference was observed at the end of reperfusion $(\mathrm{p}<0.01)$. When comparing the control groups, significantly lower amount of released h-FABP was observed in the HG group from the 100th min of the reperfusion. Comparison of $\mathrm{PC}$ groups revealed that 
release of h-FABP in the HG conditions was significantly higher than in the preconditioned NG group with the onset at the 80th min and was even more pronounced at the end of experiment $(\mathrm{p}<0.01)$.
A.

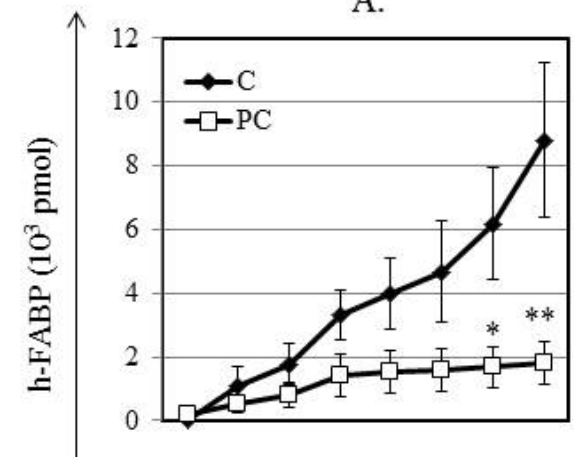

$\begin{array}{llllllll}-30 & 0 & 20 & 40 & 60 & 80 & 100 & 120\end{array}$
B.

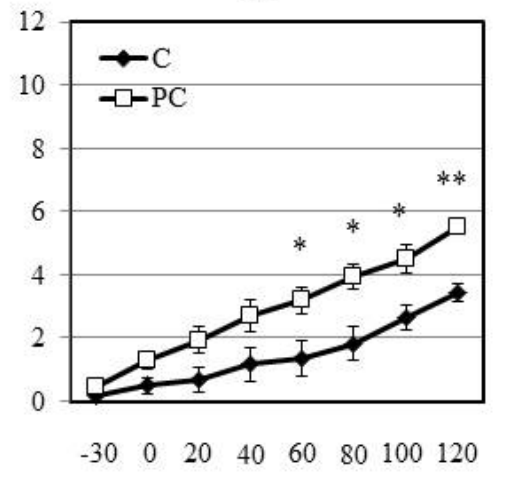

Fig. 2. Cumulative curves of h-FABP amount released from the hearts of non-PC control groups and PC groups. A: Cumulative curves under NG conditions. B: Cumulative curves under HG conditions. h-FABP amount of $h$-FABP released to effluent from hearts expressed in pmol. Results are means \pm SEM, $n=3-7$ hearts per group. * $\mathrm{p}<0.05$, $* * \mathrm{p}<0.01, \mathrm{PC}$ vs. respective non-PC group (C)

Reperfusion time [0-120 min]

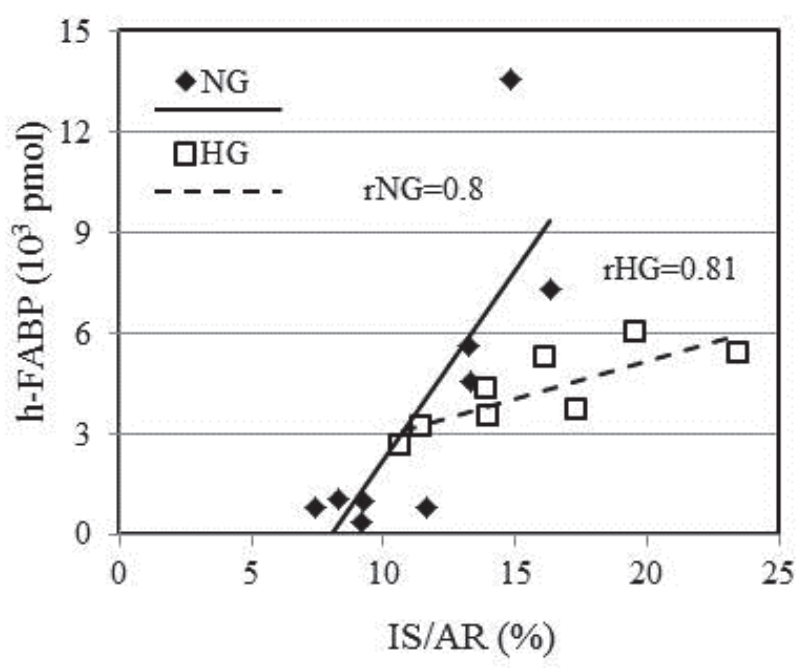

Fig. 3. Correlation of infarct size and amount of $h-F A B P$ in the effluent from the hearts at the end of long term reperfusion. IS/AR - infarct size/area at risk ratio, IS - infarct size, AR - area at risk, h-FABP - amount of h-FABP substance in effluent from hearts (in pmol) at the end of long-term reperfusion

Correlations of total h-FABP amount released from the hearts and the size of myocardial infarction

Dependence of released h-FABP on the size of infarcted area in the non-preconditioned and preconditioned hearts was assessed based on the calculation of the Pearson's correlation coefficient. Fig. 3 shows high correlation of IS/AR with h-FABP in both $\mathrm{NG}(\mathrm{rNG}=0.8)$ and $\mathrm{HG}(\mathrm{rHG}=0.81)$ conditions.

\section{Discussion}

Our study demonstrated that significantly lower amounts of h-FABP were released from the hearts after
100 min of long-term reperfusion in the PC-group than in the non-PC control group under $\mathrm{NG}$ conditions. Importantly, significantly smaller IS/AR was also observed in the PC group. Lower increase of h-FABP in the effluent can point out to a slower development of infarction, due to increased resistance to $\mathrm{I} / \mathrm{R}$ conferred by PC. Our data are in agreement with the Murry's experimental results demonstrating that PC delays the development of irreversible changes and decreases the extent of lethal injury, evoked by long-term coronary occlusion (Murry et al. 1991).

Under conditions of simulated $\mathrm{HG}$, the results were reversed. PC significantly increased IS/AR ratio that was in contrast with antiinfarct effect of PC in the $\mathrm{NG}$ group (Fig. 1A). Likewise, significantly higher amount of h-FABP was observed in the effluent from the preconditioned hearts than in the effluent from the nonPC group of hearts from $60 \mathrm{~min}$ of reperfusion (Fig. 2). It seems that PC under conditions of simulated hyperglycemia has negative effects on cardiac resistance to I/R injury. Comparison of IS/AR and total h-FABP amount in the effluent from the preconditioned and nonpreconditioned hearts under $\mathrm{NG}$ and $\mathrm{HG}$ condition indicates that hyperglycemia influences the development of infarction only in combination with PC. Thus, significantly higher IS/AR ratio and amount of h-FABP in the effluent from 80 to $120 \mathrm{~min}$ of reperfusion was observed in the $\mathrm{PC} / \mathrm{HG}$ group than in the $\mathrm{PC} / \mathrm{NG}$ group.

On the other hand, no significant differences in IS/AR were found between the NG and $\mathrm{HG}$ non-PC control groups (Fig. 1), and the amount of h-FABP released from the hearts of $\mathrm{HG}$ group was even lower in the final stages of reperfusion than in the NG group 
(Fig. 2). This finding indicates that the hearts perfused with high-glucose medium may be more resistant to ischemic injury. This is in agreement with the results of Chen et al. (2006) who have demonstrated that STZinduced severe acute hyperglycemia was associated with lower release of creatinine phosphokinase from the tissue exposed to $\mathrm{I} / \mathrm{R}$ injury and with increased heat shock protein 90 and catalase in Langendorff-perfused hearts.

Prognosis of AMI depends on its size (Sobel et al. 1972). Determined high association between the IS and total released amount of h-FABP in NG and $\mathrm{HG}$ conditions (Fig. 3) implies that h-FABP might be used as a prognosis predictor in AMI patients with a history of UAP. The utility of h-FABP as a determinant of infarct size is confirmed by the study with open-chest dogs (Sohmiya et al. 1993). Lower release of h-FABP from the hearts in the control group in HG than in NG conditions with no difference in the size of infarction between these groups demonstrated in our study might refer to protective effect of simulated acute $\mathrm{HG}$ that prevents severe myocardial injury in non-infarcted risk area and release of low molecular substances. This is in accordance with the study of Tani and Neely (1988) who found that acute diabetes prevents $\mathrm{Ca}^{2+}$ overload in rat hearts exposed to I/R injury and with the Schaffer's et al. (2000) study showing that high-glucose medium upregulates apoptotic repressor protein $\mathrm{Bcl}-2$.

In all the groups, release of h-FABP during longterm coronary occlusion was also observed. Its potential cause could be basal release from the normal myocardium, which is evident at the end of stabilization period, and coronary collateral circulation developing in AR which becomes functional between 15 and 30 min of coronary occlusion according to a morphological study in rats (Jia and Sato 1997).

Comparison of PC effectivity under $\mathrm{NG}$ and $\mathrm{HG}$ conditions was performed in the in vivo conditions in open-chest rabbits as well. PC was induced by a single $5 \mathrm{~min}$ coronary occlusion followed by a $15 \mathrm{~min}$ reperfusion (Vladic et al. 2011). In this study, PC in HG conditions had no negative effect on the IS size after I/R evoked by coronary artery occlusion. HG only abolished its beneficial effect. Similarly, attenuated but no negative effect of PC was observed in the in vivo experiments with mongrel dogs in HG group (Kersten et al. 1998). In these experiments, PC was induced by four short-term coronary artery occlusions and permanent hyperglycemia by continual intravenous infusion of glucose or dextrose. Therefore, it seems unprobable that the differences between the results of in vivo experiments and our ex vivo experiments are attributed to the differences between animal species, models or a number of PC episodes. Potential cause of negative effect of $\mathrm{PC}$ in our ex vivo experiments can be associated with elimination of beneficial action of insulin, PI3K/Akt pathway and inhibition of GSK3 $\beta$ (Yin et al. 2012). Deleterious effect of HG without the influence of insulin could be caused by lowering tetrahydrobiopterin $\left(\mathrm{BH}_{4}\right)$ cofactor of $\mathrm{NO}$ synthase confirmed by cell culture study (Prabhakar 2001). However, beneficial action of insulin is not obvious. Other cell culture studies showed that insulin promotes proapoptotic activity reflected in an increased Bcl-2 like protein 4 (BAX)/B-cell lymphoma 2-protein (Bcl-2) ratio (Ricci et al. 2008), caspase-3, cytochrome-c and Bcl-2-associated death promoter (Rajamani et al. 2011).

Studies with cultured cardiomyocytes also pointed to deleterious effect of simulated hyperglycemia alone, i.e., in the absence of insulin, due to induction of

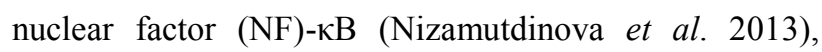
activation of protein p53 (Fiordaliso et al. 2001), mitochondrial cytochrome-C-mediated caspase-3 pathway (Cai et al. 2002) and downregulation of $\mathrm{Na}^{+} / \mathrm{K}^{+}$ATPase (Li et al. 2009).

In addition, simulated hyperglycemia attenuated protective effect of pharmacological preconditioning associated with Akt pathway in cardiomyocyte cultures (Kim et al. 2012).

A component of signal transduction of preconditioning in rat hearts is protein kinase $C-\delta$ (PKC$\delta$ ), too (Schulz et al. 2001), which can be involved in the apoptotic processes (Zhao et al. 2012). Both, mannitol and glucose treatment of rat ventricular myocytes in vitro led to activation of PKC- $\delta$ and its translocation to cell membrane (Shizukuda et al. 2002). Impaired cardioprotective signaling pathways of preconditioning and activation of PKC- $\delta$ and other proapoptotic factors under conditions of hyperglycemia can explain negative effect of PC in our experiments.

\section{Conclusion}

Our results indicate that measurement of perspective cardiomarker h-FABP released from the injured hearts after the onset of ischemia can be used as a determinant of the lethal injury and the effectivity of PC, under certain conditions. Higher release of h-FABP from the hearts in the control group perfused under standard 
NG conditions than under conditions of simulated hyperglycemia indicates that acute hyperglycemia may exert cardioprotective effects against ischemic cardiac injury. Based on the evaluation of infarct size and release of h-FABP, deleterious effect of PC under simulated acute hyperglycemia in vitro conditions may be suggested. It can be speculated that a probable cause of this negative effect could be the absence of protective influence of insulin and/or impairment of cardioprotective pathways of preconditioning.

\section{Conflict of Interest}

There is no conflict of interest.

\section{Acknowledgements}

This study was supported by grants VEGA SR 2/0054/11, APVV-LPP-0393-09, APVV-0102-11.

\section{References}

ALHADI HA, FOX KA: Do we need additional markers of myocyte necrosis: the potential value of heart fatty-acidbinding protein. QJM 97: 187-198, 2004.

BALAKUMAR RP, SHARMA NK: Healing the diabetic heart: does myocardial preconditioning work? Cell Signal 24: 53-59, 2012.

BEHAR S, REICHERREISS H, ABINADER E: The prognostic significance of angina pectoris precede the occurence of a first acute infarction in 4166 consecutive hospitalized patients. Am Heart J 12: 1481-1486, 1992.

CAI L, LI W, WANG G, GUO L, JIANG Y, KANG YJ: Hyperglycemia-induced apoptosis in mouse myocardium: mitochondrial cytochrome C-mediated caspase-3 activation pathway. Diabetes 51: 1938-1948, 2002.

CHAN CP, SANDERSON JE, GLATZ JF, CHENG WS, HEMPEL A, RENNEBERG R: A superior early myocardial infarction marker. Human heart-type fatty acid binding protein. Z Kardiol 93: 388-397, 2004.

CHEN H, SHEN WL, WANG XH, CHEN HZ, GU JZ, FU J, NI YF, GAO PJ, ZHU DL, HIGASHINO H: Paradoxically enhanced heart tolerance to ischemia in type 1 diabetes and role of increased osmolarity. Clin Exp Pharmacol Physiol 33: 910-916, 2006.

CLODFELDER-MILLER B, DE SARNO P, ZMIJEWSKA AA, SONG L, JOPE RS: Physiological and Pathological Changes in Glucose Regulate Brain Akt and Glycogen Synthase Kinase-3*. J Biol Chem 280: 39723-39731, 2005.

FEUVRAY D, LOPASCHUK GD: Controversies on the sensitivity of the diabetic heart to ischemic injury: the sensitivity of the diabetic heart to ischemic injury is decreased. Cardiovasc Res 34: 113-120, 1997.

FIORDALISO F, LERI A, CESSELI D, LIMANA F, SAFAI B, NADAL-GINARD B, ANVERSA P, KAJSTURA J: Hyperglycemia activates p53 regulated genes leading to myocyte cell death. Diabetes 50: 2363-2375, 2001.

IGLEWICZ B, HOAGLIN D: How to detect and handle outliers. In: ASQC Basic References in Quality Control: Statistical Techniques. MYKYTKA EF (ed), ASCQ Quality Press, Milwaukee, 1993.

ISHIHARA M, INOUE I, KAWAGOE T, SHIMATANI Y, KURISU S, NISHIOKA K, KOUNO Y, UMEMURA T, NAKAMURA S, SATO H: Diabetes mellitus prevents ischemic preconditioning in patients with a first acute anterior wall myocardial infarction. J Am Coll Cardiol 38: 1007-1011, 2001.

JIA YZ, SATO S: Evaluation of coronary collateral circulation in early ischemia in rat hearts. A morphological study. Nihon Ika Daikagu Zasshi 64: 329-336, 1997.

KARMAZYN M: The myocardial sodium-hydrogen exchanger (NHE) and its role in mediating ischemic and reperfusion injury. Keio J Med 47: 65-72, 1995.

KERSTEN JR, SCHMELING TJ, ORTH KG, PAGEL PS, WARLTIER DC: Acute hyperglycemia abolishes ischemic preconditioning in vivo. Am J Physiol 275: H721-H725, 1998.

KIM HS, KIM SY, KWAK YL, HWANG KC, SHIM YH: Hyperglycemia attenuates myocardial preconditioning of remifentanil. J Surg Res 174: 231-237, 2012.

KLEINE AH, GLATZ JF, VAN NIEWENHOVEN FA: Release of heart fatty acid binding protein into plasma after AMI in man. Mol Cell Biochem 116: 155-162, 1992. 
KLONER RA, SHOOK T, PRZYKLENK K, DAVIS VG, JUNIO L, MATTHEWS RV, BURSTEIN S, GIBSON M, POOLE WK, CANNON CP, ET AL.: Previous angina alters in-hospital outcome in TIMI-4. A clinical correlate to preconditioning? Circulation 91: 37-45, 1995.

KLONER RA, SHOOK T, ANTMAN EM, CANNON CP, PRZYKLENK K, YOO K, MCCABE CH, BRAUNWALD E: Prospective temporal analysis of the onset of preinfarction angina versus outcome: an ancillary study in TIMI-9B. Circulation 97: 1042-1045, 1998.

KORTHIUS RJ, GUTE DC, CEPINSKAS G, KVIETYS PR: Celular mechanisms of acute versus delayed preconditioning. Pathophysiology 5: 35-48, 1998.

LI Y, LI Y, FENG Q, ARNOLD M, PENG T: Calpain activation contributes to hyperglycemia-induced apoptosis in cardiomyocytes. Cardiovasc Res 84: 100-110, 2009.

LIU Y, THORNTON JD, COHEN MV, DOVNEY JM, SCHAFFER SW: Streptozotocin-induced non-insulindependent diabetes protects the heart from infarction. Circulation 88: 1273-1278, 1993.

MIURA T, NISHIHARA M, MIKI T: Drug developement targeting the glycogen synthase kinase-3beta (GSK-3beta)mediated signal transduction pathway: role of GSK-3beta in myocardial protection against ischemia/reperfusion injury. J Pharmacol Sci 109: 162-167, 2009.

MONITORI-GRAU M, OSORIO-CONLES O, OROZCO A, SERRANO-MARCO L, VÁZQUES-CARRERA M, GÓMEZ-FOIX AM: Glucose dependence of glycogen synthase activity regulation by GSK3 and MEK/ERK inhibitors and angiotensin-(1-7) action on these pathways in cultured human myotubes. Cell Signal 25: 13181327, 2013.

MURRY CE, JENNINGS RB, REIMER KA: New insights into potential mechanism of preconditioning. Circulation 84: 442-445, 1991.

NAKAGAWA Y, ITO H, KITAKAZE M, KUSUOKA H, HORI M, KUZUYA T, HIGASHINO Y, FUJII K, MINAMINO T: Effect of angina pectoris on myocardial protection in patients with reperfused anterior wall myocardial infarction: retrospective clinical evidence of "preconditioning". J Am Coll Cardiol 25: 1076-1083, 1995.

NIZAMUTDINOVA IT, GULERIA RS, SINGH AB, KENDAL JA, BAKER KM, PAN J: Retinoid acid protects cardiomyocytes from high glucose-induced apoptosis through inhibition of NF- $\mathrm{B}$ signaling pathway. $J$ Cell Physiol 228: 380-392, 2013.

PRABHAKAR SS: Tetrahydrobiopterin reverses the inhibition of nitric oxide by high glucose in cultured murine mesangial cells. Am J Physiol 281: F179-F188, 2001.

RAJAMANI U, JOSEPH D, ROUX S, ESSOP MF: The hexosamine biosynthetic pathway can mediate myocardial apoptosis in a rat model of diet-induced insuline resistance. Acta Physiol (Oxf) 202: 151-157, 2011.

RAVINGEROVÁ T, ŠTETKA R, PANCZA D, ULIČNÁ O, ZIEGELHÖFFER A, STYK J: Susceptibility to ischemiainduced arrhytmias and the effect of preconditioning in the diabetic rat heart. Physiol Res 49: 607-616, 2000.

RAVINGEROVÁ T, NECKÁŘ J, KOLÁŘ F: Ischemic tolerance of rat hearts in acute and chronic phase of experimental diabetes. Mol Cell Biochem 249: 167-174, 2003.

RAVINGEROVÁ T, MATEJÍKOVÁ J, ADAMEOVÁ A, NEMČEKOVÁ M, PECHAŇOVÁ O, KELLY T, SUMBALOVÁ Z, LAZOU A: Adaptive mechanism in the diabetic myocardium: an alternative form of endogenous cardioproítection and its loss. In: Adaptation Biology and Medicine. P WANG, CH KUO, N TAKEDA, PK SINGAL (eds), Narosa Publishing House, New Delhi, 2011, pp 59-75.

RICCI C, JONG CJ, SCHAFFER SW: Proapoptotic and antiapoptotic effects of hyperglycemia: role of insulin signaling. Can J Physiol 86: 166-172, 2008.

SCHAFFER SW, CROFT CB, SOLODUSHKO V: Cardioprotective effect of chronic hyperglycemia: effect on hypoxia-induced apoptosis and necrosis. Am J Physiol 278: H1948-H1954, 2000.

SCHULZ R, COHEN MV, BEHRENDS M, DOWNEY JM, HEUSCH G: Signal transduction of ischemic preconditioning. Cardiovasc Res 52: 181-198, 2001.

SHIZUKUDA Y, REYLAND ME, BUTTRICK PM: Protein kinase C-delta modulates apoptosis induced by hyperglycemia in adult ventricular myocytes. Am J Physiol 282: H1625-H1634, 2002. 
SINGH AB, GULERIA RS, NIZAMUDTINOVA IT, BAKER KM, PAN J: High glucose-induced represion of $\mathrm{RAR} / \mathrm{RXR}$ in cardiomyocytes is mediated through oxidative stress/JNK signaling. J Cell Physiol 227: 2632 2644, 2012.

SOBEL BE, BRESNAHAN GF, SHELL WE, YODER RD: Estimation of infarct size in man and its relation to prognosis. Circulation 46: 640-648, 1972.

SOHMIYA K, TANAKA T, TSUJI R, YOSHIMOTO K, NAKAYAMA Y, HIROTA Y, KAWAMURA K, MATSUNAGA Y, NISHIMURA S, MIYAZAKI H: Plasma and urinary heart-type cytoplasmatic fatty acidbinding protein in coronary occlusion and reperfusion induced myocardial injury model. $J$ Mol Cell Cardiol 25: 1413-1426, 1993.

ŠVORC P, ŠEFARA P, BARČOKOVÁ I: Ischaemic preconditioning - laboratory curiosity or endogenous protection of myocardium before ischaemia? (in Slovak) Cardiol 12: 21-27, 2003.

TANI M, NEELY J: Hearts from diabetic rats are more resistant to in vitro ischemia: possible role of altered $\mathrm{Ca}^{2+}$ metabolism. Circ Res 62: 931-940, 1988.

TOSAKI A, ENGELMAN DT, ENGELMAN RM, DAS DK: The evolution of diabetic response to ischemia/reperfusion and preconditioning in isolated working rat hearts. Cardiovasc Res 31: 526-536, 1996.

TSANG A, HAUSENLOY DJ, MOCANU MM, CARR RD, YELLON DM: Preconditioning the diabetic heart. The importance of Akt phosphorylation. Diabetes 54: 2360-2364, 2005.

TSUJI R, TANAKA T, SOHMIYA K, HIROTA Y, YOSHIMOTO K, KINOSHITA K, KUSAKA Y, KAWAMURA K, MORITA H, ABE S: Human heart-type cytoplasmatic fatty acid binding protein in serum and urine during hyperacute myocardial infarction. Int J Cardiol 41: 209-217, 1993.

VEERKAMP JH, VAN MOERKERK HTB, PRINSEN CFM, VAN KUPPEVELT TH: Structural and functional studies on different human FABP types. Mol Cell Biochem 192: 137-142, 1999.

VLADIC N, GE ZG, LEUCKER T, BRZEZINSKA AK, DU JH, SHI Y, WARLTIER DC, PRATT PF, KERSTEN JR: Decreased tetrahydrobiopterin and disrupted association of Hsp90 with eNOS by hyperglycemia impair myocardial ischemic preconditioning. Am J Physiol 301: H2130-H2139, 2011.

YADAV HN, SINGH M, SHARMA PL: Involvement of GSK-3 $\beta$ in attenuation of the cardioprotective effect of ischemic preconditioning in diabetic rat heart. Mol Cell Biochem 343: 75-81, 2010.

YIN X, ZHENG Y, ZHAI X, ZHAO X, CAI L: Diabetic inhibition of preconditioning- and postconditioning-mediated myocardial protection against ischemia/reperfusion injury. Exp Diabetes Res 2012: Article ID 198048, 2012.

YU XY, GENG YJ, LIANG JL, LIN SG, ZHANG S, LI Y: High levels of glucose induce apoptosis in cardiomyocyte via epigenetic regulation of the insulin-like growth factor receptor. Exp Cell Res 316: 2903-2909, 2010.

ZHAO M, XIA L, CHEN GQ: Protein kinase C $\delta$ in apoptosis: a brief overview. Arch Immunol Ther Exp (Warsz) 60: 361-372, 2012. 